\title{
Reaction of Microorganisms to Long-Term Waste Reclamation of Soil Degraded by the Sulfur Mining Industry
}

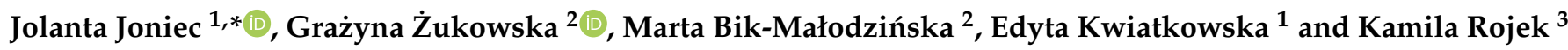 \\ 1 Department of Environmental Microbiology, Faculty of Agrobioengineering, University of Life Sciences in \\ Lublin, Leszczyńskiego 7, 20-069 Lublin, Poland; edyta.kwiatkowska@up.lublin.pl \\ 2 Institute of Soil Science and Environment Shaping, Faculty of Agrobioengineering, University of Life Sciences \\ in Lublin, Leszczyńskiego 7, 20-069 Lublin, Poland; grazyna.zukowska@up.lublin.pl (G.Ż.); \\ marta.bik-malodzinska@up.lublin.pl (M.B.-M.) \\ 3 Department of Landscape Architecture, Faculty of Horticulture and Landscape Architecture, University of \\ Life Sciences in Lublin, Głęboka 28, 20-612 Lublin, Poland; kamila.rojek@up.lublin.pl \\ * Correspondence: jolanta.joniec@up.lublin.pl; Tel.: +48-81-524-81-11
}

check for

updates

Citation: Joniec, J.; Żukowska, G.; Bik-Małodzińska, M.; Kwiatkowska, E.; Rojek, K. Reaction of

Microorganisms to Long-Term Waste Reclamation of Soil Degraded by the Sulfur Mining Industry. Minerals 2021 11, 1226. https://doi.org/10.3390/ $\min 11111226$

Academic Editors: Maxim Muravyov and Anna Panyushkina

Received: 1 October 2021

Accepted: 1 November 2021

Published: 4 November 2021

Publisher's Note: MDPI stays neutral with regard to jurisdictional claims in published maps and institutional affiliations.

Copyright: (c) 2021 by the authors. Licensee MDPI, Basel, Switzerland. This article is an open access article distributed under the terms and conditions of the Creative Commons Attribution (CC BY) license (https:/ / creativecommons.org/licenses/by/ $4.0 /)$.

\begin{abstract}
The research was carried out to assess soil condition many years after waste introduction for reclamation purposes. The parameters of the activity of soil microorganisms responsible for the revitalization processes in degraded soils were used in the research. Soil material was derived from the area of the former sulfur mine. The results showed that even a single waste introduction to degraded soil caused long-lasting effects in the activity of soil microorganisms. The most favorable changes were caused by the addition of sewage sludge and the use of mineral wool in the form of a pad. The application of lime alone turned out to be the least beneficial for the revitalization processes, i.e., restoring the homeostasis of biological life in degraded soil. This research is a continuation of study that concerned the initial recultivation period. The obtained research results show the need for monitoring soils reclaimed with waste, not only in the initial period but also in the following years. These results allow evaluation of the usefulness of the parameters of soil microbial activity in monitoring soil environments subjected to strong human pressure. The results can be used to assess the risks associated with the introduction of waste into the environment.
\end{abstract}

Keywords: bacteria and fungi; enzymes; biochemical activity; waste; main waste; degraded soil; reclamation; risk assessment

\section{Introduction}

Soil is one of the most important natural resources and forms the basis for the functioning of terrestrial ecosystems [1,2]. It has a number of important functions, among others, it enables primary production of biomass and circulation of carbon and other elements; it also has an effect on the micro- and macroclimate and shapes biodiversity [3]. Soil formed as a result of long-term interaction of soil-forming factors is characterized by a specific homeostasis due to such processes as filtration, buffering, or the transformation of chemical compounds, including pollutants. Various types of human pressure exerted on the soil environment lead to disturbance or even total destruction of this balance [2,4]. The result is a decrease in the utility value of the soil and its elimination from agricultural use. Soil has the ability to reproduce its resources, mainly due to the abundant and diverse microbiota. Qualitative and quantitative composition of soil microbiocenoses plays a very important role in the course of many biological processes, and its changes affect the proper functioning of ecosystems [5].

It should be emphasized that these are heterotrophic soil microorganisms that are the main producers of enzymes catalyzing processes occurring in soil, and their activity affects soil fertility [6,7]. Soil bacteria and fungi determine soil biochemistry, and thus their activity and diversity are considered important indicators of soil fertility and productivity [8]. The 
enzymatic and respiratory activity of soil microorganisms is utilized to assess the condition of degraded and reclaimed soils [9-11].

However, the return of a degraded soil environment to equilibrium is a long-term process, and its course and effect depends on the type and degree of degradation. However, it can be accelerated by taking appropriate corrective actions. The primary purpose of reclamation treatments is to restore biological life in degraded soil. Actions are taken to improve the environmental conditions of heterotrophic soil bacteria and fungi. One of such methods is the introduction of waste material, among others, sewage sludge, composts, mineral wool, lime, tree litter, sawdust, spent mushroom substrate, manure, biochar [10,12-18]. The results of the studies cited above have shown that the soil reaction increased, aggregate structure improved, and higher $\mathrm{C}$ and $\mathrm{N}$ content and sorption capacity can be observed in soils recultivated with the use of this waste. In addition, heavy metals are being immobilized and soil quality increases, and the development and activity of soil microorganisms also intensifies.

The sulfur mining industry is an example of a strong, negative interference that man exerts on the soil environment [19]. This phenomenon was strongly present in the area of the former Jeziórko sulfur mine (Podkarpackie Voivodeship, Poland). Sulfur deposits in this area belong to one of the largest in the world (Piaseczno-Machów-Jeziórk-Jamnica). In the years 1967-2001, over 74 million Mg of sulfur was extracted in the Jeziórko mine using the Frasch borehole method. This is an underground melting method in which sulfur is extracted using hot water introduced under pressure [20,21]. Sulfur borehole mining based on this method caused a deep soil degradation on many levels, consequently leading to the biological imbalance and even die-off of biological life.

Earlier studies have shown that the introduction of various wastes to degraded soil from the area of the former sulfur mine resulted in the intensification of the development and activity of soil microbial organisms in the initial period $[10,15,22]$. The obtained results indicated the need for further monitoring of changes in the activity of bacteria and fungi in the reclaimed soil. It should be emphasized that, from the point of view of the effectiveness of undertaken reclamation methods, not only is the direction of the changes important, but also their persistence. It is therefore essential to control the stability of the renewing ecosystems.

The presented study was aimed not only at analyzing the effectiveness of a single reclamation treatment, but also at assessing the stability of the ecosystem that has formed over a period of 7 years. For this purpose, studies were undertaken to assess changes in the development of bacteria and fungi as well as their respiratory and enzymatic activity in the reclaimed soil. These studies provide valuable information on the long-term effects of a single introduction of waste to degraded soil. The obtained research results will allow to minimize the risk associated with excessive waste introduction into the soil environment.

\section{Materials and Methods}

\subsection{Description of the Experiment}

The soil material was derived from a reclamation experiment established in the closed sulfur mine "Jeziórko" in south-eastern Poland $\left(50^{\circ} 33^{\prime} 09^{\prime \prime} \mathrm{N}, 21^{\circ} 46^{\prime} 40^{\prime \prime} \mathrm{E}\right)$, (Figure 1). Sulfur was mined using the Frasch method, i.e., hot water melting through boreholes.

The following wastes were introduced into the soil degraded by exploitation for reclamation purposes: post-flotation lime (PFL), sewage sludge (SS), and mineral wool (MWP — in the form of a pad, MW—-fragmented and distributed in the soil). NPK mineral fertilization was also applied. The characteristics of the degraded soil and the applied waste are presented in Table 1. 

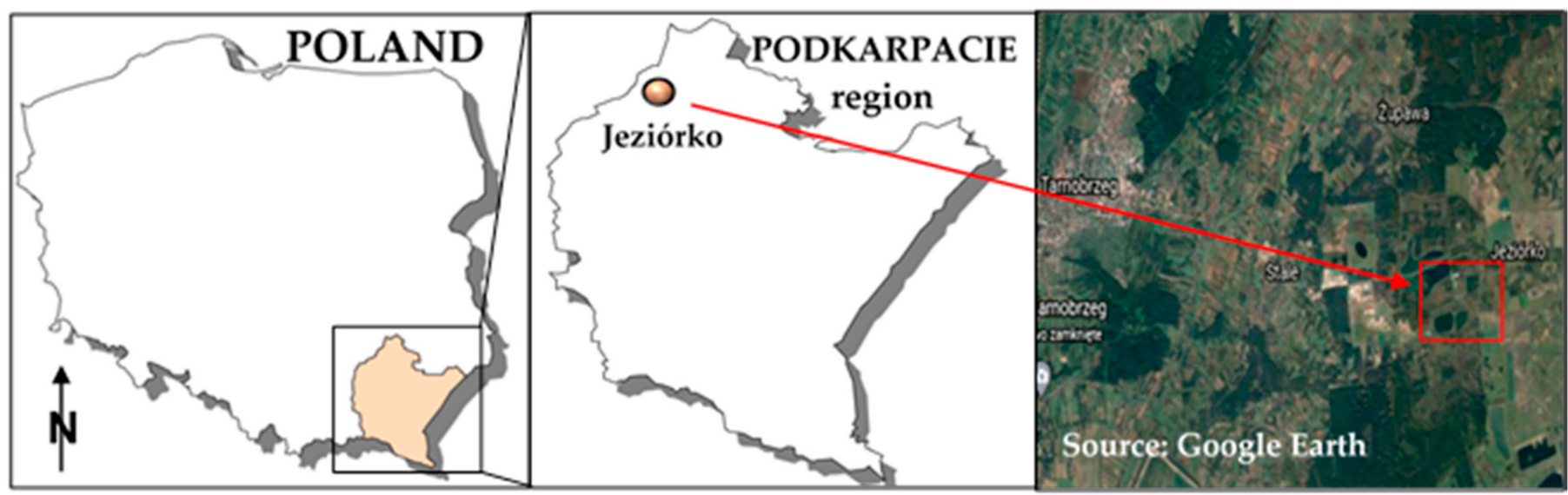

Figure 1. Location of area studied and general overview.

Table 1. Selected properties of the degraded ground and the wastes used for remediation [10].

\begin{tabular}{|c|c|c|c|c|c|}
\hline Property & Unit & $\begin{array}{l}\text { Degraded } \\
\text { Soil }\end{array}$ & $\begin{array}{c}\text { Mineral } \\
\text { Wool }\end{array}$ & $\begin{array}{l}\text { Sewage } \\
\text { Sludge }\end{array}$ & $\begin{array}{l}\text { Flotation } \\
\text { Lime }\end{array}$ \\
\hline \multirow{3}{*}{$\begin{array}{l}\text { Particle size } \\
\text { distribution }\end{array}$} & $\%$ sand & 91 & \multirow{3}{*}{ n.o. } & \multirow{3}{*}{ n.o. } & 35 \\
\hline & $\%$ silt & 3 & & & 29 \\
\hline & $\%$ fine fract. & 6 & & & 36 \\
\hline $\mathrm{pH}$ & $1 \mathrm{~mol} \mathrm{KCl}$ & 4.3 & $5.3-6.6$ & 6.4 & 6.8 \\
\hline $\mathrm{T}$ & $\operatorname{cmol}(+) \cdot \mathrm{kg}^{-1}$ & 7.0 & 60.9 & 54.5 & 122.9 \\
\hline $\mathrm{N}$ total & \multirow{2}{*}{$\mathrm{g} \cdot \mathrm{kg}^{-1}$} & 0.3 & 5.3 & 28.0 & 10.4 \\
\hline Corg. & & 2.0 & 28.5 & 193.8 & 2.6 \\
\hline
\end{tabular}

Wastes were used in the following variants: soil without changes, control (UNP); lime + NPK (PFL, NPK); lime + sewage sludge (PFL, SS); sewage sludge (SS); lime + wool $5 \mathrm{~cm} \cdot 50 \mathrm{~cm}^{-1}+$ NPK (PFL, MWP, NPK); lime + wool $5 \mathrm{~cm} \cdot 50 \mathrm{~cm}^{-1}$ + sewage sludge (PFL, MWP, SS); lime + wool $500 \mathrm{~m}^{3} \cdot \mathrm{ha}^{-1}+\mathrm{NPK}$ (PFL, MW, NPK); lime + wool $500 \mathrm{~m}^{3} \cdot \mathrm{ha}^{-1}+$ sewage sludge (PFL, MW, SS). The plots were sown with a reclamation mixture of various types of grass and clover. A detailed description of the experiment can be found in the study of Joniec et al. [22]. Table 2 presents selected soil properties in the 6th and 7th years of the experiment.

Table 2. Selected physical, physicochemical and chemical properties of the soil (means for the year).

\begin{tabular}{|c|c|c|c|c|c|c|c|c|}
\hline \multirow[t]{2}{*}{ Experimental Treatments } & \multicolumn{2}{|c|}{$\begin{array}{c}\text { Sorptive } \\
\text { Capacity T, } \\
\text { cmol(+)kg }^{-1}\end{array}$} & \multicolumn{2}{|c|}{$\begin{array}{l}\text { Corg., } \\
\text { g·kg }{ }^{-1}\end{array}$} & \multicolumn{2}{|c|}{$\begin{array}{l}\text { N Total, } \\
\mathrm{g} \cdot \mathrm{kg}^{-1}\end{array}$} & \multicolumn{2}{|c|}{ PH } \\
\hline & Year 6 & Year7 & Year 6 & Year 7 & Year 6 & Year 7 & Year 6 & Year 7 \\
\hline UNP (control) & 7.0 & 7.8 & 2.03 & 1.83 & 0.32 & 0.32 & 4.2 & 4.7 \\
\hline PFL + NPK & 14.4 & 15.0 & 2.52 & 2.18 & 0.44 & 0.35 & 7.5 & 7.5 \\
\hline PFL + SS & 15.5 & 20.5 & 4.20 & 4.43 & 1.06 & 1.05 & 6.9 & 6.9 \\
\hline SS & 8.7 & 8.7 & 4.50 & 4.65 & 0.53 & 0.63 & 6.5 & 5.4 \\
\hline $\mathrm{PFL}+\mathrm{MWP}+\mathrm{NPK}$ & 14.9 & 19.7 & 3.98 & 3.88 & 0.54 & 0.55 & 7.4 & 7.3 \\
\hline PFL + MWP + SS & 15.6 & 17.8 & 4.47 & 3.90 & 1.37 & 1.33 & 7.1 & 7.0 \\
\hline $\mathrm{PFL}+\mathrm{MW}+\mathrm{NPK}$ & 14.6 & 16.3 & 3.40 & 3.45 & 0.35 & 0.36 & 7.4 & 7.3 \\
\hline $\mathrm{PFL}+\mathrm{MW}+\mathrm{SS}$ & 15.7 & 17.4 & 5.50 & 4.85 & 0.67 & 0.63 & 6.9 & 6.8 \\
\hline
\end{tabular}

Abbreviations: UNP-control soil; PFL + NPK-post-flotation lime and NPK; PFL + SS-post-flotation lime and sewage sludge; SS-sewage sludge; PFL + MWP + NPK-post-flotation lime, mineral wool pad $\left(5 \mathrm{~cm} \cdot 50 \mathrm{~cm}^{-1}\right)$, and NPK; PFL + MWP + SS-post-flotation lime, mineral wool pad $\left(5 \mathrm{~cm} \cdot 50 \mathrm{~cm}^{-1}\right)$, and sewage sludge; PFL + MW + NPK-post-flotation lime, mineral wool $\left(500 \mathrm{~m}^{3} \cdot \mathrm{ha}^{-1}\right)$, and NPK; PFL + MW + SS-post-flotation lime, mineral wool $\left(500 \mathrm{~m}^{3} \cdot \mathrm{ha}^{-1}\right)$, and sewage sludge.

\subsection{Soil Samples}

Samples for analysis were collected in the 6th and 7th years of the reclamation treatments, twice a year, i.e., in spring (Time point I and III) and in autumn (Time point II and IV). Soil samples were collected randomly from the center of each site to sterile containers. 
The average soil sample from each plot consisted of a mixture of 10 soil cores, $4 \mathrm{~cm}$ in diameter each. The collected material was sieved through a $2 \mathrm{~mm}$ sieve and stored at $4{ }^{\circ} \mathrm{C}$.

\subsection{Microbiological Analyses}

The count of the following groups of bacteria and fungi was determined in the soil material using the plate method [23]: oligotrophic bacteria using a medium with soil extract and $\mathrm{K}_{2} \mathrm{HPO}_{4}(\mathrm{pH} 7$ ) and total fungi using Martin's medium (pH 5.5) [24]. Cultures were incubated at $28^{\circ} \mathrm{C}$ by 7 days (bacteria) and $25^{\circ} \mathrm{C}$ by 3 days (fungi). The results are presented as colony-forming unit $\mathrm{cfu} \mathrm{kg}^{-1} \mathrm{dm}$ soil.

\subsection{Biochemical and Enzymatic Analyses}

Respiratory activity was determined by titration in $20 \mathrm{~g}$ soil samples with the addition of $1 \%$ glucose (Chempur, product of Poland) [25]; the activity was expressed as mg C-CO $\mathrm{Cg}_{2} \mathrm{~kg}^{-1} \mathrm{dm}$ soil d $\mathrm{d}^{-1}$, Dehydrogenase activity was determined by the method of Thalmann [26] using 2, 3, 5-triphenyl tetrazolium chloride (TTC, Sigma-Aldrich, cityWien,

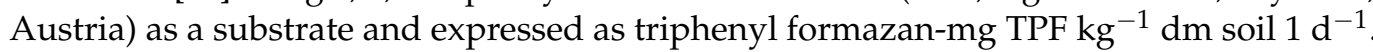
Urease activity was determined using the Zantua and Bremner method [27] in $10 \mathrm{~g}$ soil samples with urea (Chempur, product of Poland) as a substrate and expressed as mg $\mathrm{N}-\mathrm{NH}_{4} \mathrm{~kg}^{-1} \mathrm{dm}$ soil $18 \mathrm{~h}^{-1}$. The activity of acid phosphatase was determined according to the method of Tabatabai and Bremner [28] in $1 \mathrm{~g}$ soil samples using 4-nitrophenyl phosphate disodium salt hexahydrate (PNPNa, Sigma-Aldrich, Burlington, MA, USA) as a substrate and expressed as para-nitrophenol-mg PNP kg ${ }^{-1} \mathrm{dm} \mathrm{soil} \mathrm{h}^{-1}$. Arylsulfatase activity was determined using the Tabatabai and Bremner method [29] in $1 \mathrm{~g}$ soil samples with potassium 4-nitrophenyl sulfate (PNS, Sigma-Aldrich, Burlington, MA, USA) as a substrate; the activity was expressed as para-nitrophenol-mg PNP kg ${ }^{-1} \mathrm{dm} \mathrm{soil} \mathrm{h}^{-1}$. Fluorescein diacetate (FDA, Sigma-Aldrich, Burlington, MA, USA) hydrolytic activity was determined by the Schnurer and Rosswall method [30] in $1 \mathrm{~g}$ soil samples with the addition of FDA as a substrate and expressed as mg fluorescein $\mathrm{kg}^{-1} \mathrm{dm} \mathrm{soil} \mathrm{h}^{-1}$.

\subsection{Statistical Analysis}

All analyses were performed in three parallel repetitions and presented as a mean of these repetitions. The results obtained were statistically analyzed in the STATISTICA ver. 13.0 (StatSoft. Inc., Tulsa, OK, USA) software with ANOVA models and multiple Tukey's T-tests at the significance level of $\alpha=0.05$. To verify whether ANOVA assumptions were met, including dataset normality and homogeneity of the variance, the Shapiro-Wilk and Levene tests were used, respectively, and they showed that indeed those criteria were met. The results are shown in the graphs with standard deviation indicated. The relationships of the studied microbial counts, respiration and enzymatic activities at individual sites and time points were analyzed using principal component analysis (PCA). The obtained results were additionally correlated with the outcomes concerning chemical parameters presented in Table 2.

\section{Results}

The results presented in Figure 2A showed that the introduction of waste to the degraded soil resulted in changes in the total bacterial count. The analysis of the results showed that the number of bacteria in the reclaimed objects was higher from the second time point $\left(0.320-2.210 \mathrm{cfu} 10^{9} \mathrm{~kg}^{-1}\right)$ compared to the non-reclaimed site $\left(0.120-0.753 \mathrm{cfu} 10^{9} \mathrm{~kg}^{-1}\right)$. The described effect was visible with varying intensity, depending on the type of waste used and the date of testing. Stimulation of the development of the studied groups of bacteria was most clearly visible in the sites where sewage sludge was introduced separately or together with other waste (PFL + SS; SS; PFL + MWP + SS; PFL + MW + SS) and mineral wool, in the form of a pad, with the addition of lime and NPK (PFL + MWP + NPK). Contrary to the above-mentioned time points, there was a decrease in bacterial growth in the reclaimed sites at time point I (except for combination SS). The total number of bacteria 
at that time point was $0.050-0.900 \mathrm{cfu} 10^{9} \mathrm{~kg}^{-1}$. The highest decrease in this parameter was recorded for the combination of wool in the form of a pad used together with sewage sludge (PFL + MWP + SS).
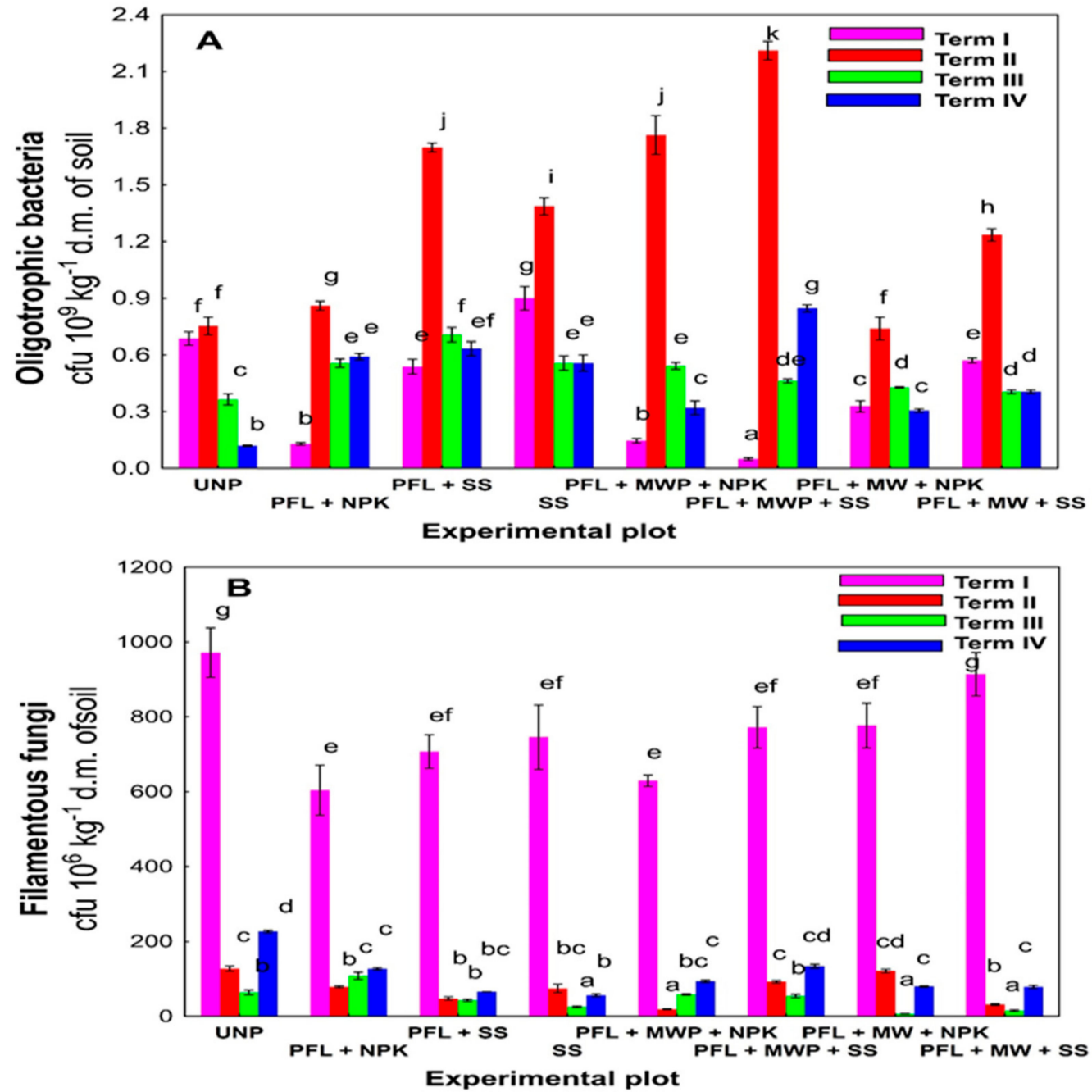

Figure 2. Number of selected groups of bacteria and fungi in reclaimed soil. (A) Oligotrophic bacteria; (B) - Fliamentous fungi; UNP-degraded soil without changes, control; PFL + NPK-lime with NPK; PFL + SS-lime with sewage sludge; SS—sewage sludge; PFL + MWP + NPK-lime with wool $5 \mathrm{~cm}$

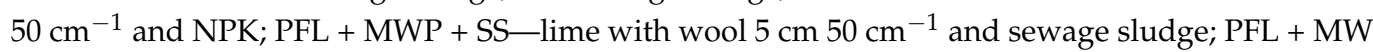
+ NPK-lime with wool $500 \mathrm{~m}^{3} \mathrm{ha}^{-1}$ and NPK; PFL + MW + SS-lime with wool $500 \mathrm{~m}^{3} \mathrm{ha}^{-1}$ and sewage sludge. Term I-June/6th year, Term II-October/6th year, Term III-June/7th year, Term IV-October /7th year. The vertical lines indicate the standard deviation. Different letters above the columns indicate significant differences.

The results obtained for the number of filamentous fungi (Figure 2B) showed that this parameter was still subject to significant changes many years after the reclamation was applied. The development of filamentous fungi was different at individual time points. The highest number of fungi was recorded in time point I (971.42-604.14 cfu $\left.10^{6} \mathrm{~kg}^{-1}\right)$ and the lowest in time point III $\left(6.73-108.54 \mathrm{cfu} 10^{6} \mathrm{~kg}^{-1}\right)$. As opposed to bacteria, years of reclamation treatments resulted in a decrease in the number of these fungi. Inhibition of this parameter showed different intensity in individual sites and time points and did not have a constant trend. Inhibition persisting at all time points was reported in combination of sewage sludge applied together with lime (PFL + SS) and separately (SS). 
The results concerning respiratory activity in the analyzed soil (Figure 3A) indicated that the introduction of waste a few years ago had a significant stimulating effect on this parameter. Higher activity at the sites with waste compared to control soil was clearly visible from the second time point. The greatest stimulation of respiratory activity occurred under the influence of sewage sludge used in combination with lime (PFL + SS) and sludge alone (SS). In these combinations, the activity was $167.95-233.96 \mathrm{mg} \mathrm{kg}^{-1}$ and 159.83-266.03 $\mathrm{mg} \mathrm{kg}^{-1}$, respectively, while only $15.01106 .08 \mathrm{mg} \mathrm{kg}^{-1}$ in the unreclaimed soil. Lime (PFL + NPK) turned out to be the least favorable for this biochemical parameter, which was the only one that caused a decrease in the first and third time point. Respiratory activity in these cases reached the lowest values of $6.53 \mathrm{mg} \mathrm{kg}^{-1}$ and $34.72 \mathrm{mg} \mathrm{kg}^{-1}$. The positive impact of other waste combinations (PFL + MWP + NPK, PFL + MWP + SS, PFL + MW + NPK, PFL + MW + SS) was at a similar level.
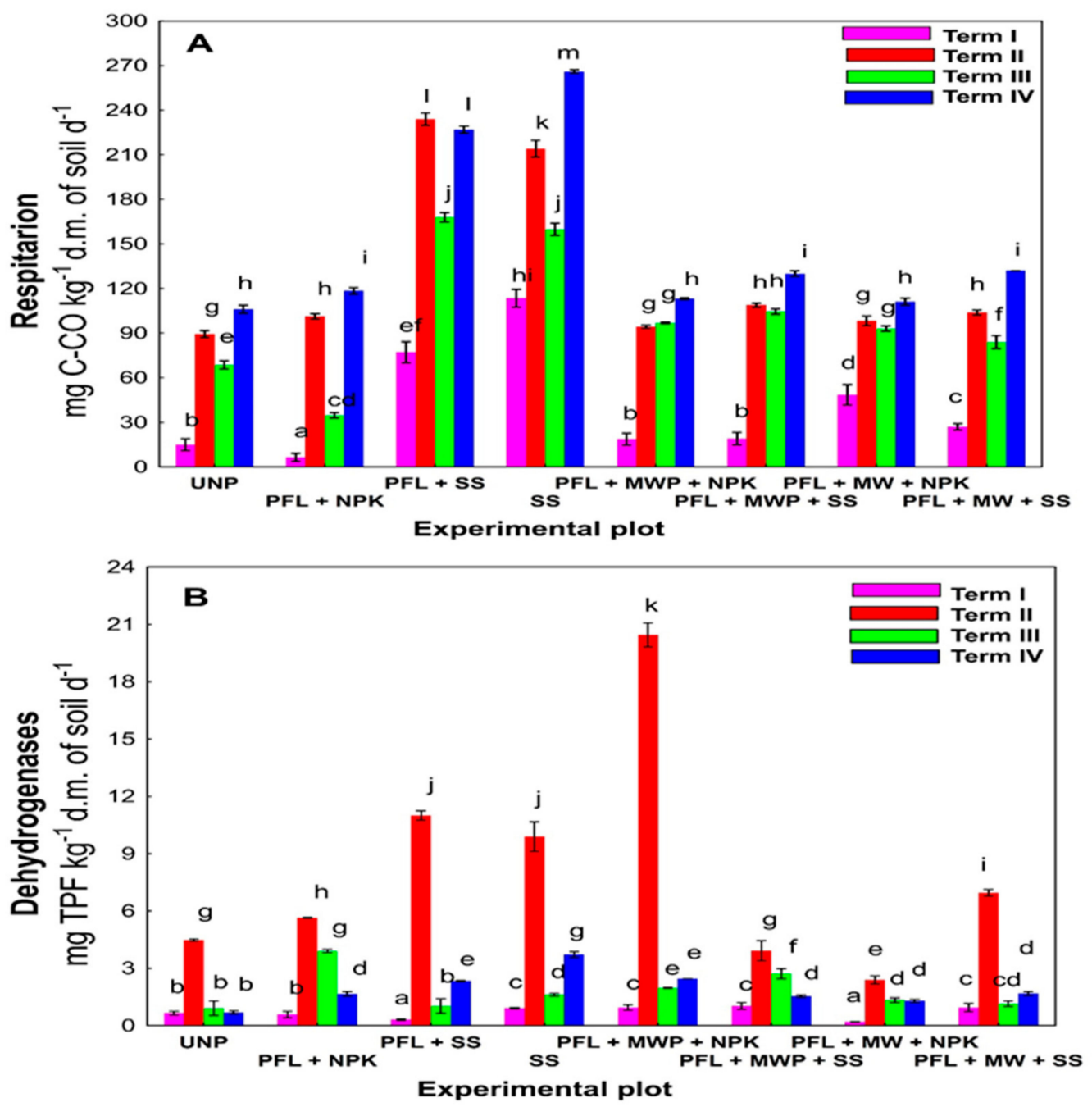

Figure 3. Biochemical and enzymatic activity in reclaimed soil. (A)-Respiration; (B)Dehydrogenases activity. The vertical lines indicate the standard deviation. Different letters above the columns indicate significant differences. Explanations as in Figure 2.

The analysis of the activity of dehydrogenase, urease, and arylsulfatase enzymes in the 6th and 7th years of the experiment showed an increased level of these enzymes in the reclaimed soil (Figures 3B and 4A,B). This effect was visible with varying intensity depending on the type of waste used and time point. 

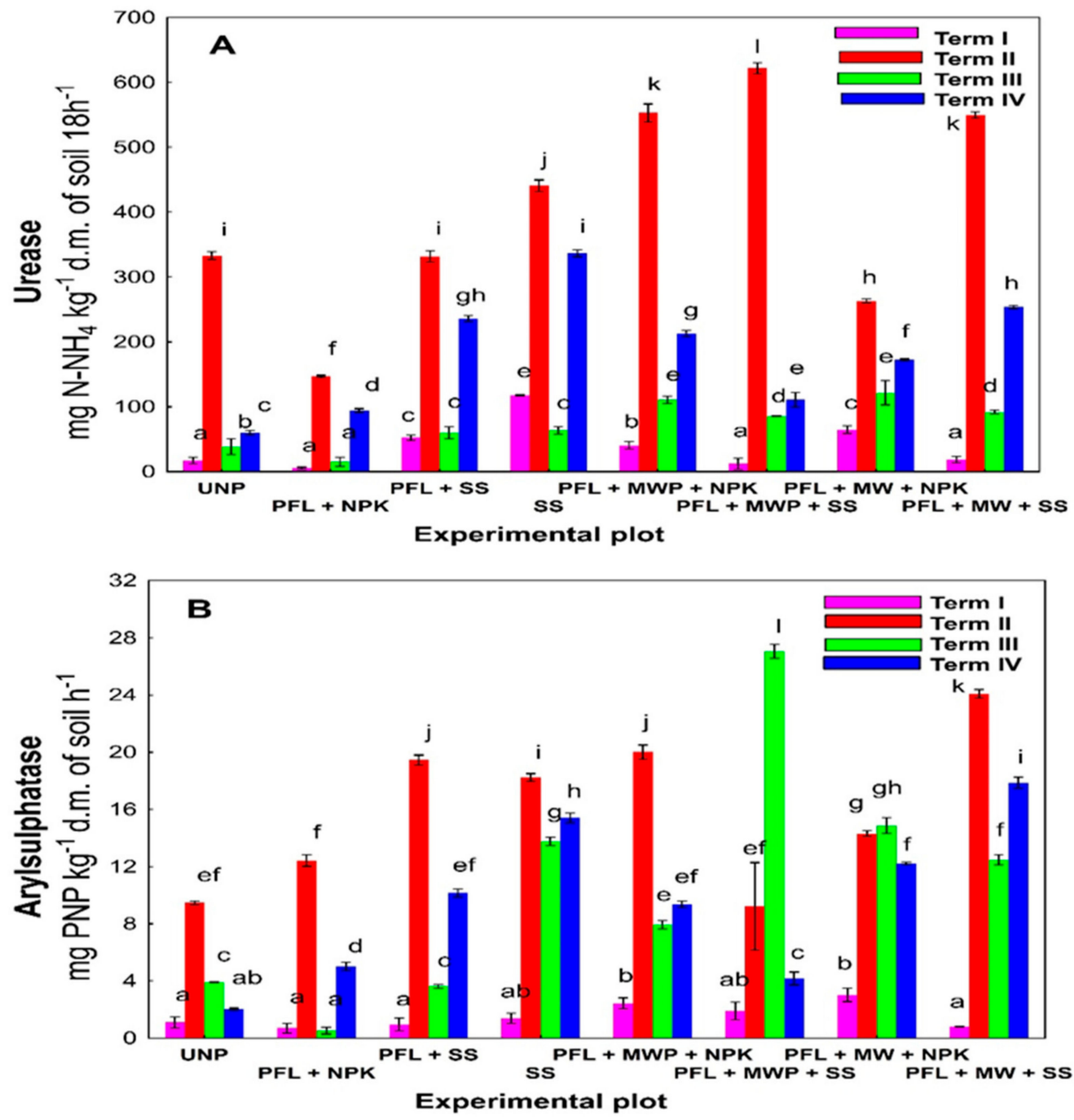

Figure 4. Enzymatic activity in reclaimed soil. (A)—Urease activity; (B)-Arylsulphatase activity. The vertical lines indicate the standard deviation. Different letters above the columns indicate significant differences. Explanations as in Figure 2.

The values of dehydrogenase activity in the reclaimed sites ranged from $0.204-20.449 \mathrm{mg} \mathrm{kg}^{-1}$, and $0.653-4.475 \mathrm{mg} \mathrm{kg}^{-1}$ in the control soil (Figure 3B). This activity was most strongly stimulated at time point II. The highest values were obtained in sites with sewage sludge and wool in the form of a pad and lime (PFL + MWP + NPK), followed by the site with sewage sludge applied in combination with lime (PFL + SS) and separately (SS). The values of dehydrogenase activity in these objects ranged from $9.899-20.449 \mathrm{mg} \mathrm{kg}^{-1}$, while it was $0.653-4.475 \mathrm{mg} \mathrm{kg}^{-1}$ in the control soil (Figure 2B). The introduction of wool mixed with soil and lime (PFL + MW + NPK) into the degraded soil turned out to be the least beneficial for this activity. The addition of these wastes resulted in a decrease in this enzymatic activity in the 6th year after their introduction, i.e., at time points I and II. The lowest value of dehydrogenase activity $\left(0.204 \mathrm{mg} \mathrm{kg}^{-1}\right)$ was recorded in this combination.

The data in Figure 4A,B show that urease and arylsulfatase activity was most highly stimulated from the second time point on sites with sewage sludge applied separately and together with other wastes (PFL + SS; SS; PFL + MWP + SS; PFL + MW + SS) and in combination with mineral wool in the form of a pad with Ca and NPK (PFL + MWP + NPK). Urease activity was in the range of $63.85-621.95 \mathrm{mg} \mathrm{kg}^{-1}$, and arylsulfatase- $-3.936-27.07 \mathrm{mg} \mathrm{kg}^{-1}$. Urease activity in the control site was in the range of $38.83-332.92 \mathrm{mg} \mathrm{kg}^{-1}$, and arylsulfatase$3.936-9.46 \mathrm{mg} \mathrm{kg}^{-1}$. The least favorable for these enzymatic activities was the application 
of lime (PFL + NPK) and mineral wool mixed with soil together with lime and NPK $(\mathrm{PFL}+\mathrm{MW}+\mathrm{NPK})$. At the site with lime $(\mathrm{PFL}+\mathrm{NPK})$, a decrease in urease activity was noted at certain time points.

The impact of individual reclamation treatments was not uniform in the case of hydrolytic activity of fluorescein (Figure 5A) and acid phosphatase (Figure 5B). An increase or decrease in these parameters was recorded in individual objects and test dates. FDA hydrolytic activity was stimulated more frequently than acid phosphatase. Hydrolytic activity ranged from 28.18 to $181.34 \mathrm{mg} \mathrm{kg}^{-1}$ in the reclaimed sites and $47.30-98.71 \mathrm{mg} \mathrm{kg}^{-1}$ in the control object. The highest values were recorded in the autumn periods, i.e., time point II and IV. Stimulation of this parameter in most time points was observed in combinations with sewage sludge alone (SS), sludge with wool in the form of a pad (PFL + MWP + SS), and wool in the form of a pad in combination with lime and NPK (PFL + MWP + NPK). There was a decrease or increase in this activity at other sites (PFL + NPK, PFL + SS, $\mathrm{PFL}+\mathrm{MW}+\mathrm{NPK}, \mathrm{PFL}+\mathrm{MW}+\mathrm{SS}$ ). The inhibition was noticeable in the spring time points, i.e., I and III. The lowest values of the discussed activity were recorded in combination with sewage sludge used together with wool mixed with soil and lime (PFL + MW + SS).
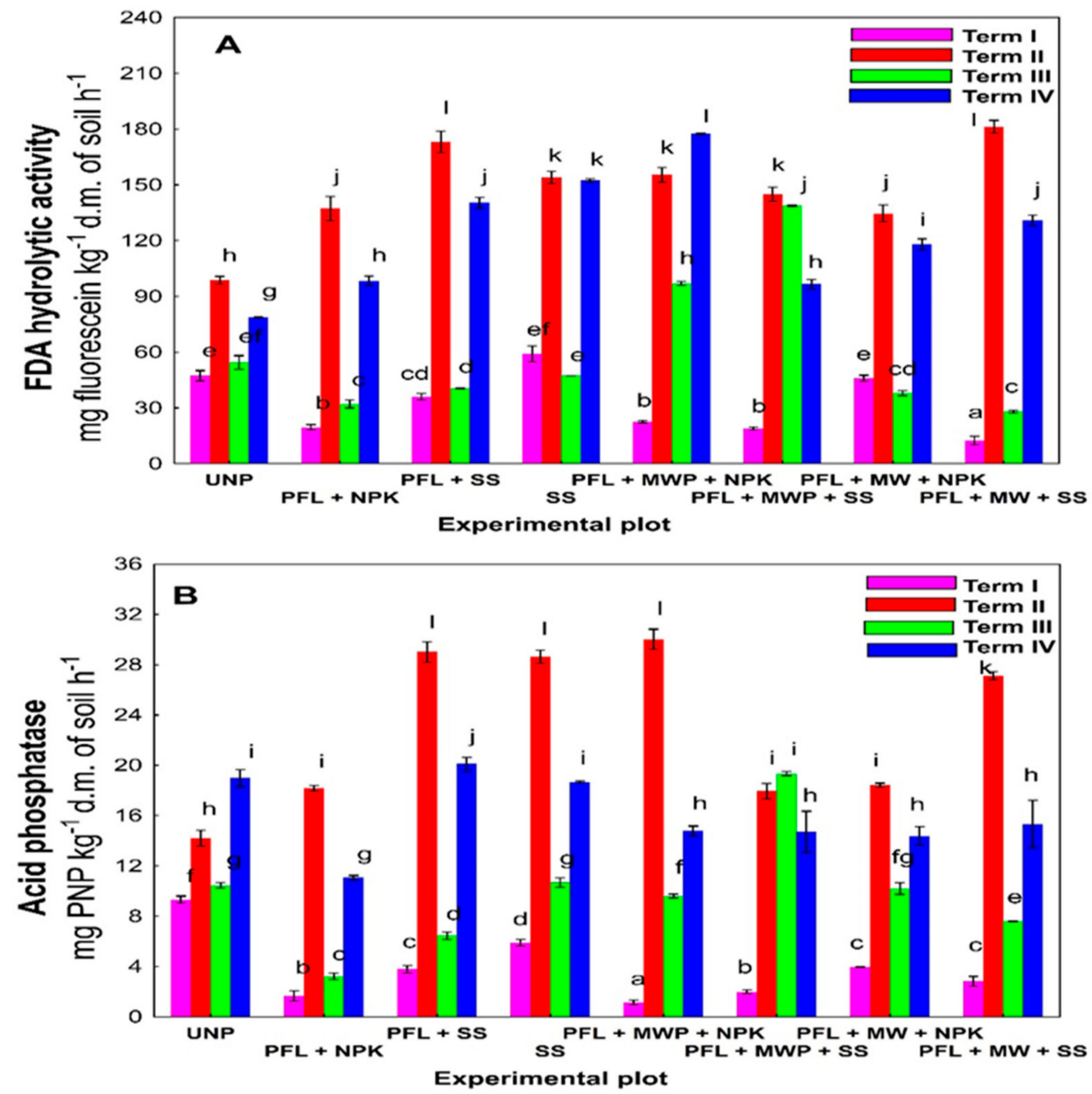

Figure 5. Enzymatic activity in reclaimed soil, cont. (A)_FDA hydrolytic activity; (B)—Acid phosphatase activity. The vertical lines indicate the standard deviation. Different letters above the columns indicate significant differences. Explanations as in Figure 2.

Phosphatase activity ranged from 1.14 to $30.02 \mathrm{mg} \mathrm{kg}^{-1}$ in the reclaimed sites, and $9.33-18.98 \mathrm{mg} \mathrm{kg}^{-1}$ in the control object. This parameter was most often subject to inhibi- 
tion. This effect was most frequent and strongest in the site with lime (PFL + NPK), with wool in the form of a pad with lime and NPK (PFL + MWP + NPK) and wool mixed with soil and applied with sludge and lime (PFL $+\mathrm{MW}+\mathrm{SS})$. The least frequent (only in one time point) inhibition of the discussed activity occurred in the site with sewage sludge alone (SS). Stimulation of phosphatase activity was recorded in the second time point in all reclaimed sites. The values of this parameter ranged from $18.40-30.02 \mathrm{mg} \mathrm{kg}^{-1}$, while it was $14.22 \mathrm{mg} \mathrm{kg}^{-1}$ in control. The most beneficial were combinations with sewage sludge $(\mathrm{PFL}+\mathrm{SS}, \mathrm{SS}, \mathrm{PFL}+\mathrm{MW}+\mathrm{SS})$ and the combination with wool in the form of a pad with lime and NPK (PFL + MWP + NPK).

\section{Discussion}

Previous studies on this model [15] demonstrated that sewage sludge had the most beneficial effect on the development of oligotrophic bacteria also in the initial period, i.e., three years of reclamation. With time, the number of bacteria decreased in both reclaimed and control sites. Earlier studies on fungal development also showed a decrease in the number of filamentous fungi in the initial reclamation period [15]. However, this phenomenon was more visible in sites with mineral wool than with sewage sludge. As in the case of bacteria, the count of filamentous fungi was also lower in the 6th and 7th years compared to the first years of reclamation.

Inhibition of fungal growth observed in the conditions of the discussed experiment was a positive phenomenon because it reduced the probability of the occurrence of pathogenic and mycotoxin-producing species [31].

The obtained results showed that the stimulation of bacterial growth was accompanied by an increase in enzymatic and respiratory activity. This is a normal phenomenon indicating the return of soil to homeostasis because, as Kuzyacov [6] wrote, heterotrophic soil microorganisms are the main producers of enzymes and $\mathrm{CO}_{2}$ in soils. The decrease in the development of filamentous fungi accompanying bacterial growth stimulation indicated that prokaryotic microorganisms played the main role in the mineralization of waste matter in these conditions. This was also confirmed by the negative correlation of the number of filamentous fungi and respiration (Figure 6A).

The observed stimulation of bacterial growth as well as respiratory and enzymatic activity in the reclaimed soil was probably related to the elevated levels of $\mathrm{C}$ and $\mathrm{N}$ and the sorption complex, which continued in the following years (Table 2). An increase in soil $\mathrm{pH}$ was also observed in the reclaimed sites (Table 2). The most favorable effect of sewage sludge was caused by the introduction of organic matter along with this waste, which permanently contributed to the increase of the above parameters in the soil. Comparison of the results with the results of enzymatic activity and respiration obtained in the first years of reclamation $[10,15]$ showed that the most beneficial effect of sewage sludge persisted over time. Moreover, as with respiration, enzymatic activity generally increased over the years. Halecki and Klatka [32], in research on reclamation of post-industrial areas, stated that eight years of reclamation with sewage sludge enriched with amendments was long enough to improve the physical properties of this soils.

Zukowska et al. [33] showed that sewage sludge used for reclamation contributed to the formation of permanent humus forms. Improvement of other environmental conditions in the soil recultivated with sewage sludge also contributed to the observed increase in bacterial growth. A study by Singh and Agrawal [34] demonstrated that sewage sludge, when introduced into the soil, exerted a broad and positive effect on the biological life of the soil environment by affecting organic matter, nutrient content, soil porosity, bulk density, aggregate structure, and water capacity. The research of Liang et al. [35] showed that organic fertilization had a more beneficial effect on the activity of dehydrogenases and urease than mineral fertilization, which indicated that organic fertilization was more effective than mineral fertilization as a method to permanently increase soil fertility. The dependence of enzymatic activity on the availability of carbon and nitrogen organic matter was demonstrated, among others [4,10,36-38]. The observed long-term stimulation of 
enzymatic and biochemical activities on sites reclaimed by sewage sludge was probably also related to the fact that many exoenzymes become stabilized through association with clay minerals, humic acids, and particulate organic matter, and retain significant levels of activity for prolonged periods [36].
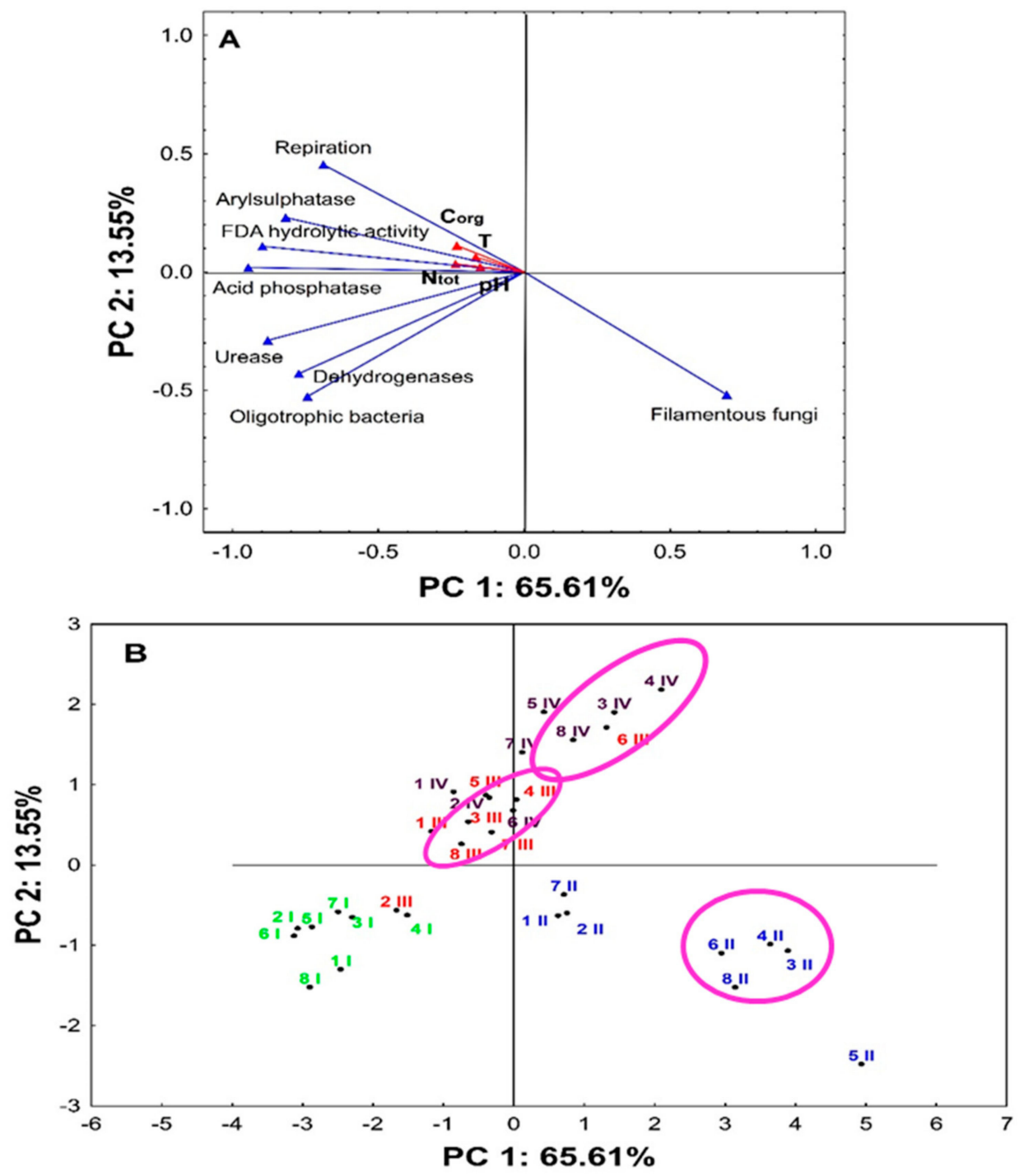

Figure 6. Principal component analysis (PCA), loading plot (A) and score plot (B), for the results of analyzed parameters in the soil. (1) UNP-degraded soil without changes, control; (2) PFL + NPKlime with NPK; (3) PFL + SS—lime with sewage sludge; (4) SS—sewage sludge; (5) PFL + MWP +

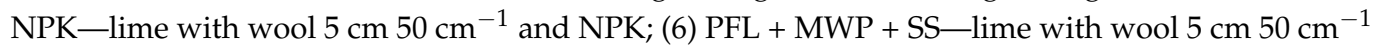
and sewage sludge; (7) PFL + MW + NPK-lime with wool $500 \mathrm{~m}^{3} \mathrm{ha}^{-1}$ and NPK; (8) PFL + MW + SS-lime with wool $500 \mathrm{~m}^{3} \mathrm{ha}^{-1}$ and sewage sludge. Corg- $\mathrm{C}$ organic; Ntot-N total; T-sorption capacity. Terms: I-June/6th year, II-October/6th year, III-June/7th year, IV-October/7th year.

Stimulation of certain parameters of microbial activity, also observed in some sites with mineral wool and lime, could be caused by the improvement of such properties as water capacity, nitrogen balance, or soil density [12,39]. McTee et al. [40] indicated $\mathrm{CaCO}_{3}$ application as the most effective method to improve ecological properties of acidic soils contaminated with elemental sulfur.

The dependence of the discussed microbial activity on the chemical and physicochemical soil properties under the conditions of this experiment was confirmed by the loading plot (Figure 6A). A positive correlation was particularly evident between the content of 
C, N, sorption capacity and respiration, arylsulfatase activity, FDA hydrolytic activity, and acid phosphatase. Moreover, the activity of dehydrogenases, ureases and the abundance of oligotrophic bacteria showed a clear positive correlation with $\mathrm{pH}$. A negative relationship was noted for filamentous fungi with respiration, $\mathrm{C}$ and $\mathrm{N}$ content, and soil sorption capacity.

The increase in the number of bacteria, respiration and enzymatic activities in reclaimed sites, and intensification of this effect over the years (except for the number of bacteria) proved the effectiveness of reclamation treatments $[10,15,22]$. This was particularly true with respect to sewage sludge application. The above observations were also confirmed by principal component analysis (PCA), which showed clustering of sites with sewage sludge, especially clearly visible for time points II, III, and IV (Figure 6B). Such a distribution indicated that the level of the analyzed parameters of microbial activity in the sites recultivated with sewage sludge (separately and in combination with other wastes) differed from the sites without sewage sludge. The differences in microbial, biochemical, and enzymatic activity were determined in $13.55 \%$ by factor 1 (PC1) and in $65.61 \%$ by factor 2 (PC2). Moreover, the most favorable effect of sewage sludge on the tested parameters of soil microbial activity, persisting in the 6th and 7th years, proved that it was the most effective reclamation variant under the tested conditions.

\section{Conclusions}

The obtained results showed that even a single waste introduction to degraded soil for the purpose of reclamation causes long-lasting effects in the activity of soil microorganisms. However, these effects were not uniform. There was a clear positive effect of reclamation treatments on bacterial growth, respiration, dehydrogenase, urease, and arylsulfatase activity, and to a lesser extent on fluorescein hydrolytic activity. The effect on fungal growth and hydrolase activity was generally negative. The decrease in the number of fungi shown in the present study is a favorable phenomenon from the point of view of soil revitalization because it reduces the risk associated with the presence of mycotoxin-producing or phytopathogenic species. The noted increase in bacterial growth, the inhibition of fungal growth, and a simultaneous increase in respiratory and enzymatic activity indicate favorable proportions in the population of soil microorganisms from the point of view of microbiological transformation of matter in the soil environment.

It should be noted that the most favorable changes were caused by the addition of sewage sludge and the application of mineral wool in the form of a pad. The application of lime alone turned out to be the least beneficial for the revitalization processes, i.e., restoring the homeostasis of biological life in degraded soil. It is worth emphasizing that all analyzed microbiological, biochemical, and enzymatic activities underwent significant changes that persisted 6 and 7 years from the beginning of reclamation. This indicated high sensitivity of these parameters and their usefulness in monitoring the long-term effects of soil remediation.

The study results showed the necessity of monitoring soils reclaimed with waste not only in the initial period, but also in the following years.

Author Contributions: Conceptualization, J.J.; methodology, J.J.; software, J.J. and E.K.; validation, J.J.; formal analysis, J.J.; investigation, J.J., G.Ż., M.B.-M. and E.K.; resources, J.J., G.Ż., M.B.-M.; data curation, J.J.; writing-original draft preparation, J.J. and K.R.; writing-review and editing, J.J.; visualization, J.J., E.K. and K.R.; supervision, J.J.; project administration, J.J., G.Ż., M.B.-M.; funding acquisition, J.J. All authors have read and agreed to the published version of the manuscript.

Funding: This work was financially supported by the University of Life Sciences in Lublin.

Data Availability Statement: Additional information is provided by the corresponding author.

Conflicts of Interest: The authors declare no conflict of interest. 


\section{References}

1. Lehmann, J.; Bossio, D.A.; Kögel-Knabner, I.; Rillig, M.C. The concept and future prospects of soil health. Nat. Rev. Earth Environ. 2020, 1, 544-553. [CrossRef]

2. Kumar, N. Natural and Artificial Soil Amendments for the Efficient Phytoremediation of Contaminated Soil. In Phyto and Rhizo Remediation; Arora, N.K., Kumar, N., Eds.; Springer Nature: Singapore, 2019; pp. 1-32.

3. Silver, W.L.; Perez, T.; Mayer, A.; Jones, A.R. The role of soil in the contribution of food and feed. Phil. Trans. R. Soc. B 2021, 376, 20200181. [CrossRef] [PubMed]

4. Carlson, J.; Saxena, J.; Basta, N.; Hundal, L.; Busalacchi, D.; Dick, R.P. Application of organic amendments to restore degraded soil: Effects on soil microbial properties. Environ. Monit. Assess. 2015, 187, 109. [CrossRef] [PubMed]

5. Cavigelli, M.A.; Robertson, G.P. The functional significance of denitrifier community composition in a terrestrial ecosystem. Ecology 2000, 81, 1404-1414. [CrossRef]

6. Kuzyakov, Y. Sources of $\mathrm{CO}_{2}$ efflux from soil and review of partitioning methods. Soil Biol. Biochem. 2006, 38, 425-448. [CrossRef]

7. Nannipieri, P.; Kandeler, E.; Ruggiero, P. Enzyme activities and microbial and biochemical processes in soil. In Enzymes in the Environment: Activity, Ecology and Applications; Burns, R.G., Dick, R.P., Eds.; Marcel Dekker: New York, NY, USA, 2002; pp. 1-34.

8. Liang, B.; Ma, C.; Fan, L.; Wang, Y.; Yuan, Y. Soil amendment alters soil physicochemical properties and bacterial community structure of a replanted apple orchard. Microbiol. Res. 2018, 216, 1-11. [CrossRef]

9. Alvarenga, P.; Rodrigues, D.; Mourinha, C.; Palma, P.; de Varennes, A.; Cruz, N.; Tarelho, L.A.C.; Rodrigues, S. Use of wastes from the pulp and paper industry for the remediation of soils degraded by mining activities: Chemical, biochemical and ecotoxicological effects. Sci. Total Environ. 2019, 686, 1152-1163. [CrossRef]

10. Joniec, J. Enzymatic activity as an indicator of regeneration processes in degraded soil reclaimed with various types of waste. Int. J. Environ. Sci. Technol. 2018, 15, 2241-2252. [CrossRef]

11. Narendrula-Kotha, R.; Nkongolo, K.K. Changes in enzymatic activities in metal contaminated and reclaimed lands in Northern Ontario (Canada). Ecotoxicol. Environ. Saf. 2017, 140, 241-248. [CrossRef]

12. Baran, S.; Wójcikowska-Kapusta, A.; Żukowska, G.; Bik, M.; Szewczuk, C.; Zawadzki, K. Role of mineral wool and sewage sludge in increasing the nitrogen content in soilless reclaimed formations. Chem. Ind. 2012, 91, 1259-1262.

13. Dai, Z.; Zhang, X.; Tang, C.; Muhammad, N.; Wua, J.; Brookes, P.C.; Xu, J. Potential role of biochars in decreasing soil acidificationa critical review. Sci. Total Environ. 2017, 581-582, 601-611. [CrossRef] [PubMed]

14. Gąsior, J.; Właśniewski, S.; Drozd, I.; Kreczkiwska, H.; Nazarkiewicz, M. Effect of organic additives on vegetation of plants grown in landfill soil after ozokerite processing. Pol. J. Environ. Stud. 2016, 25, 2373-2385. [CrossRef]

15. Joniec, J. Indicators of microbial activity in the assessment of soil condition subjected to several years of reclamation. Ecol. Indic. 2019, 98, 686-693. [CrossRef]

16. Likus-Cieślik, J.; Pietrzykowski, M.; Chodak, M. Chemistry of sulfur-contaminated soil substrate from a former frasch extraction method sulfur mine leachate with various forms of litter in a controlled experiment. Water, Soil, Air Pollut. 2018, 229, 71. [CrossRef]

17. Sekaran, U.; Sandhu, S.S.; Qiu, Y.; Kumar, S.; Gonzalez Hernandez, J.L. Biochar and manure addition influenced soil microbial community structure and enzymatic activities at eroded and depositional landscape positions. Land Degrad. Dev. 2019, 31, 894-908. [CrossRef]

18. Zornoza, R.; Acosta, J.A.; Faz, A.; Bååth, E. Microbial growth and community structure in acid mine soils after addition of different amendments for soil reclamation. Geoderma 2016, 272, 64-72. [CrossRef]

19. Pietrzykowski, M.; Daniels, W.L. Estimation of carbon sequestration by pine (Pinus sylvestris L.) ecosystems developed on reforested post-mining sites in Poland on differing mine soil substrates. Ecol. Eng. 2014, 73, 209-218. [CrossRef]

20. Likus-Cieślik, J.; Pietrzykowski, M.; Szostak, M.; Szulczewski, M. Spatial distribution and concentration of sulfur in relation to vegetation cover and soil properties on a reclaimed sulfur mine site (Southern Poland). Environ. Monit. Assess. 2017, $189,87$. [CrossRef]

21. Siwik-Ziomek, A.; Brzezińska, M.; Lemanowicz, J.; Koper, J.; Szarlip, P. Biological parameters in technogenic soils of a former sulphur mine. Int. Agrophys. 2018, 32, 237-245. [CrossRef]

22. Joniec, J.; Oleszczuk, P.; Jezierska-Tys, S.; Kwiatkowska, E. Effect of reclamation treatments on microbial activity and phytotoxicity of soil degraded by the sulphur mining industry. Environ. Poll. 2019, 252 (Part B), 1429-1438. [CrossRef]

23. Foght, J.; Aislabie, J. Enumeration of Soil Microorganisms. In Manual of Soils Analysis. Part 5. Monitoring and Assessing Soil Bioremediation; Margesin, R., Schinner, F., Eds.; Springer: Berlin/Heidelberg, Germany, 2005; pp. 261-280.

24. Martin, J. Use of acid, rose bengal and streptomycin in the plate method for estimating soil fungi. Soil Sci. 1950, 19, 215-233. [CrossRef]

25. Rühling, A.; Tyler, G. Heavy metal pollution and decomposition of spruce needly litter. Oikos 1973, 24, 402-415. [CrossRef]

26. Thalmann, A. Zur Methodik der Bestimmung der Dehydrogenaseactivität in Boden mittels Triphenyltetrazolium chlorid (TTC). Landwirtsch. Forsch. 1968, 21, 249-258.

27. Zantua, M.J.; Bremner, J.M. Comparison of methods of assaying urease activity in soils. Soil Biol, Biochem. 1975, 7, 291-295. [CrossRef]

28. Tabatabai, M.A.; Bremner, J.M. Use of p-nitrophenol phosphate for assay of soil phosphatase activity. Soil Biol. Biochem. 1969, 1, 301-307. [CrossRef]

29. Tabatabai, M.A.; Bremner, J.M. Arylsulfatase activity of soils. Soil Sci. Soc. Am. Proc. 1970, 34, 225-229. [CrossRef] 
30. Schnurer, J.; Rosswall, T. Fluorescein Diacetate Hydrolysis as a measure of total microbial acticity in soil and litter. Appl. Environ. Microbiol. 1982, 43, 1256-1261. [CrossRef] [PubMed]

31. Frąc, M.; Jezierska-Tys, S.; Yaguchi, T. Occurrence, detection, and molecular and metabolic characterization of heat-resistant fungi in soils and plants and their risk to human health. Adv. Agron. 2015, 132, 161-204. [CrossRef]

32. Halecki, W.; Klatka, S. Aplication of Soil Productivity Index after Eight Years of Soil Reclamation with Sewage Sludge Amendments. Environ. Manage. 2021, 67, 822-832. [CrossRef] [PubMed]

33. Żukowska, G.; Baran, S.; Wójcikowska-Kapusta, A. The organic carbon content and fractional composition of organic matter in ground reclaimed with sewage sludge. Chem. Ind. 2012, 91, 1267-1269.

34. Singh, R.P.; Agrawal, M. Potential benefis and risks of land application of sewage sludge. Waste Manage. 2008, 28, 347-358. [CrossRef] [PubMed]

35. Liang, Q.; Chen, H.; Gong, Y.; Yang, H.; Fan, M.; Kuzyakov, Y. Effects of 15 years of manure and mineral fertilizers on enzyme activities in particle-size fractions in a North China Plain soil. Eur. J. Soil Biol. 2014, 60, 112-119. [CrossRef]

36. Burns, R.G.; DeForest, J.L.; Marxsen, J.; Sinsabaugh, R.L.; Stromberger, M.E.; Wallenstein, M.D.; Weintraub, M.N.; Zoppini, A. Soil enzymes in a changing environment: Current knowledge and future directions. Soil Biol. Biochem. 2013, 58, 216-234. [CrossRef]

37. Castillo, J.M.; Romero, E.; Fernandez-Bayo, J.; Vivas, A.; Nogales, R. Effect of natural vegetation strips and herbicides on enzyme activities and bacterial diversity in olive-orchard systems. In Soil Enzymology in the Recycling of Organic Wastes and Environmental Restoration; Trasar-Cepeda, C., Hernandez, T., Garcia, C., Gonzalez-Carcedo, S., Eds.; Springer: London, UK, 2012 ; pp. $255-270$.

38. Pajares, S.; Gallardo, J.; Etchevers, D. Enzymatic activity and carbon mineralization in Mexican tepetates cultivated under different management practices. In Soil Enzymology in the Recycling of Organic Wastes and Environmental Restoration; Trasar-Cepeda, C., Hernandez, T., Garcia, C., Gonzalez-Carcedo, S., Eds.; Springer: London, UK, 2012; pp. 51-62.

39. Baran, S.; Hermann, J.; Żukowska, G.; Wójcikowska-Kapusta, A. Mineral wool in environmental shaping and protection. In Environmental Waste Utilisation. Theoretical and Practical Basics; Baran, S., Łabętowicz, J., Krzywy, E., Eds.; WRiL: Warsaw, Poland, 2011; pp. 120-149.

40. McTee, R.M.; Lekberg, Y.; Bullington, L.; Rummel, A.; Mummey, D.L.; Ramsey, P.W.; Hinman, N.W. Restoring ecological properties of acidic soils contaminated with elemental sulfur. Sci. Total Environ. 2017, 587-588, 449-450. [CrossRef] [PubMed] 